\title{
Productive and reproductive performance in cattle infected with bovine leukosis virus
}

\author{
BY JOSÉ LUIZ D'ANGELINO, MAURÍCIO GARCIA* \\ AND EDUARDO HARRY BIRGEL \\ Faculty of Veterinary Medicine, Universidade de São Paulo, Brazil \\ * Department of Veterinary Medicine, Health Science Institute, Universidade Paulista, \\ Brazil
}

(Received 27 March 1997 and accepted for publication 14 May 1998)

Economic losses caused by enzootic bovine leukosis (EBL) have been of interest since World War II, when the neoplastic form of EBL increased dramatically in Europe. Olson (1974) and House et al. (1975) showed that animals with lymphosarcoma caused by the bovine leukosis virus (BLV) had reduced milk yields, a less efficient reproductive performance and high veterinary costs and mortality rates, while many carcasses were rejected at slaughter. However, the actual impact of BLV infection in cattle without lymphosarcoma is not clear. The purpose of the study reported here was to compare some productive and reproductive responses of cattle that were antibody-positive $(\mathrm{BLV}+)$ or negative $(\mathrm{BLV}-)$ for $\mathrm{BLV}$.

Holstein dairy cows in commercial dairy farms were used in this study. Blood samples were collected and subjected to BLV serological examination by the agar gel immunodiffusion test of Miller \& van der Maaten (1976). Animals were then grouped as $\mathrm{BLV}+$ or BLV - according to their serological response to the BLV antigen. Productive and reproductive histories were obtained from individual animal records and the following factors were considered: milk production, calving interval and birth rate. For milk production, we had the daily milk yields of 547 animals, and for calving interval the time between two successive parturitions for 444 cows. These values were examined by ANOVA and when this was significant a Student's $t$ test was carried out for each age group. Birth rates, the percentage of animals that calved in 1 year, were available for 557 animals and were examined with the Z-two proportion test. For all analyses, $P<0.05$ was considered significant.

\section{RESULTS AND DISCUSSION}

Mean daily milk yield was lower by $11 \%$ in BLV + than in BLV - cattle $(19 \cdot 4$ $v .21 \cdot 8 \mathrm{~kg}$; Table 1) and this was significant or approached significance for some age groups. This agrees with the findings of Reinhardt et al. (1988) and Brenner et al. (1989), who found decreases in milk yield of 3 and $3.5 \%$ respectively. However, Langston et al. (1978), Huber et al. (1981) and Burridge et al. (1982) found no differences in the milk production of $\mathrm{BLV}+$ and $\mathrm{BLV}-$ cattle.

No differences were found in the reproductive characteristics investigated (calving interval and birth rate; see Tables 2 and 3). These results agree with the observations of previous workers (Langston et al. 1978; Huber et al. 1981; Brenner 
Table 1. Milk production in Holstein dairy cows seropositive or seronegative for bovine leukosis virus

(Values are $\mathrm{kg} / \mathrm{d}$, means $\pm \mathrm{SD}$ with no. of animals in parentheses)

\begin{tabular}{cll} 
Age, years & \multicolumn{1}{c}{ Seropositive } & \multicolumn{1}{c}{ Seronegative } \\
$<4$ & $18 \cdot 6 \pm 4 \cdot 3(187)$ & $20 \cdot 5 \pm 4 \cdot 5 \dagger(123)$ \\
$4-5$ & $19 \cdot 8 \pm 4 \cdot 3(48)$ & $23 \cdot 9 \pm 4 \cdot 3 \dagger(30)$ \\
$5-6$ & $21 \cdot 7 \pm 6 \cdot 0(45)$ & $24 \cdot 6 \pm 4 \cdot 6^{*}(21)$ \\
$6-7$ & $20 \cdot 8 \pm 5 \cdot 4(35)$ & $23 \cdot 2 \pm 2 \cdot 7(4)$ \\
$7-8$ & $20 \cdot 7 \pm 6 \cdot 6(16)$ & $23 \cdot 4 \pm 2 \cdot 6(8)$ \\
$>8$ & $17 \cdot 9 \pm 9 \cdot 4(20)$ & $23 \cdot 1 \pm 5 \cdot 7(10)$ \\
Total & $19 \cdot 4 \pm 5 \cdot 2(351)$ & $21 \cdot 8 \pm 4 \cdot 7 \dagger(196)$
\end{tabular}

Values were significantly different from those for seropositive cows: $* P<0 \cdot 05$.

$\dagger$ Values for $P$ were between $0 \cdot 05$ and $0 \cdot 1$.

Table 2. Calving interval in Holstein dairy cows seropositive or seronegative for bovine leukosis virus

\begin{tabular}{ccc}
\multicolumn{2}{c}{ (Values are means \pm sD with no. of animals in parentheses) } \\
Age, years & Seropositive & Seronegative \\
$<4$ & $499 \pm 12(124)$ & $440 \pm 109(81)$ \\
$4-5$ & $456 \pm 4(47)$ & $453 \pm 103(30)$ \\
$5-6$ & $496 \pm 169(46)$ & $466 \pm 118(21)$ \\
$6-7$ & $503 \pm 168(35)$ & $429 \pm 63(4)$ \\
$7-8$ & $511 \pm 198(18)$ & $523 \pm 179(9)$ \\
$>8$ & $545 \pm 211(21)$ & $521 \pm 196(10)$ \\
Total & $474 \pm 144(291)$ & $455 \pm 121(155)$
\end{tabular}

Table 3. Birth rate in Holstein dairy cows seropositive or seronegative for bovine leukosis virus

(Values are percentages calving in 1 year, means \pm SD with no. of animals in parentheses)

$\begin{array}{ccc}\text { Age, years } & \text { Seropositive } & \text { Seronegative } \\ <4 & 79 \cdot 5(190) & 86 \cdot 7(128) \\ 4-5 & 80 \cdot 9(42) & 59 \cdot 4(32) \\ 5-6 & 78 \cdot 7(47) & 71 \cdot 4(21) \\ 6-7 & 68 \cdot 6(35) & 50 \cdot 0(4) \\ 7-8 & 61 \cdot 1(18) & 77 \cdot 8(9) \\ >8 & 68 \cdot 2(21) & 66 \cdot 7(9) \\ \text { Total } & 76 \cdot 8(353) & 78 \cdot 8(203)\end{array}$

et al. 1989) who also failed to demonstrate any impairment of reproductive efficiency in $\mathrm{BLV}+$ cattle.

To summarize, we found that BLV infections may be associated with a fall in milk production, but reproductive performance appeared to be unaffected.

\section{REFERENCES}

Brenner, J., van Haam, M., Savir, D. \& Trainin, Z. 1989 The implication of BLV infection in the productivity, reproductive capacity and survival rate of a dairy cow. Veterinary Immunology and Immunopathology 22 299-305

Burridge, M. J., Thurmond, M. C., Puhr, D. M., Wilcox, C. J. \& Simerl, N. A. 1982 Preliminary studies on impact of bovine leukaemia virus infection on dairy productivity. Proceedings, 4th International Symposium on Bovine Leukosis, Bologna 599-605. Boston, MA: Martinus Nijhoff

House, J. A., Glover, F. L. \& House, C. 1975 Current aspects of bovine leukemia. Proceedings, 8th Annual Conference of the American Association of Bovine Practitioners 147-150 
Huber, N. L., Digiacomo, R. F., Evermann, J. F. \& Studer, E. 1981 Bovine leukemia virus infection in a large Holstein herd. I. Cohort analysis of the prevalence of antibody-positive cows. II. Prospective comparison of production and reproductive performance in antibody-negative and antibody-positive cows. American Journal of Veterinary Research 42 1474-1481

Langston, A., Ferdinand, G. A. A., Ruppanner, R., Theilen, G. H., Drlica, S. \& Behymer, D. 1978 Comparison of production variables of bovine leukemia virus in antibody-negative and antibody-positive cows in two California dairy herds. American Journal of Veterinary Research 39 1093-1098

Miller, J. M. \& van der MaAten, M. J. 1976 Serological detection of bovine leukemia virus infection. Veterinary Microbiology 1 195-202

Ouson, C. 1974 Bovine lymphosarcoma (leukemia). A synopsis. Journal of the American Veterinary Medical Association 165 630-632

Reinhardt, G., Hochstein-Mintzel, V., Reidemann, S., Leal, H. \& Niedda, M. 1988 [Serological survey of enzootic bovine leukosis in Valdivia and its relationship with milk production and reproductive characteristics.] Journal of Veterinary Medicine B 35 178-185 